\title{
Changes in lipid peroxide and antioxidant enzyme activities in corpora lutea during pseudopregnancy in rats
}

\author{
K. Shimamura ${ }^{\mathrm{I}}$, N. Sugino ${ }^{1}$, Y. Yoshida ${ }^{1}$, Y. Nakamura $^{1}$, K. Ogino $^{2}$ \\ and H. Kato ${ }^{\text {I* }}$ \\ ${ }^{1}$ Department of Obstetrics and Gynecology, Yamaguchi University School of Medicine, 1144 Kogushi, \\ Ube, 755 Japan; and ${ }^{2}$ Department of Public Health. School of Medicine, Kanazawa University, 13-1 \\ Takara-machi, Kanazawa, 920 Japan
}

\begin{abstract}
This study investigated the involvement of lipid peroxidation and antioxidant enzymes in the regulation of luteal function in pseudopregnant rats. The activities of superoxide dismutase (SOD), a specific scavenger of superoxide radicals, and glutathione peroxidase, a scavenger of hydrogen peroxide, and lipid peroxide concentrations were measured in the corpus luteum on days $1,3,5,7,9,11$ and 13 of pseudopregnancy. The activity of SOD in the corpus luteum gradually increased until day 9 of pseudopregnancy and decreased thereafter, in a similar manner to serum progesterone concentration. Glutathione peroxidase activity significantly increased from day $I$ to day 3 and remained high until day 11 of pseudopregnancy. The concentrations of lipid peroxides in the corpus luteum increased from day 3 to day 13 of pseudopregnancy. The involvement of prostaglandin $F_{2 a}\left(\mathrm{PGF}_{2 \alpha}\right)$ in the production of lipid peroxides in regression of the corpus luteum was investigated by administering $\mathrm{PGF}_{2 \alpha}\left(3 \mathrm{mg} \mathrm{kg}^{-1}\right.$, s.c.) or saline on days 7,9 and 12 of pseudopregnancy. Each group of rats was autopsied $2 \mathrm{~h}$ later, and SOD activity, glutathione peroxidase activity and the concentration of lipid peroxides in the corpus luteum were determined. PGF significantly increased lipid peroxide concentrations in the corpus luteum on days 7,9 and 12 of pseudopregnancy (approximately twofold increases on days 7 and 9, and a fivefold increase on day 12 , compared with the control that received saline). The activity of SOD in the corpus luteum was significantly increased by $\mathrm{PGF}_{2 \alpha}$ on days 7 and 9, but not on day 12 , of pseudopregnancy. $\mathrm{PGF}_{2 \alpha}$ did not cause any significant changes in glutathione peroxidase activity in the corpus luteum on days 7, 9 and 12 of pseudopregnancy. It is concluded that lipid peroxides play an important role in regulating luteal function in pseudopregnant rats.
\end{abstract}

\section{Introduction}

Reactive oxygen species are increased in the corpus luteum during the regression phase (Sawada and Carlson, 1989, 1991. 1994a; Riley and Behrman, 1991; Aten et al., 1992; Sugino et al., 1993a) and inhibit progesterone production in rats (Behrman and Preston, 1989; Behrman and Aten, 1991; Gatzuli et al., 1991; Sugino et al., 1993b; Kodaman et al., 1994; Musicki et al., 1994). Corpora lutea also contain antioxidant enzymes such as superoxide dismutase (SOD) and glutathione peroxidase $\left(\mathrm{GP}_{\mathrm{x}}\right)$. Superoxide radicals are scavenged to hydrogen peroxide by a specific inhibitor, SOD, and further scavenged to $\mathrm{H}_{2} \mathrm{O}$ by $\mathrm{GP}_{\mathrm{x}}$ or catalase. Sugino et al. (1993a) and Sugino and Kato (1994) reported that $\mathrm{SOD}$ and $\mathrm{GP}_{\mathrm{x}}$ activities in the corpus luteum change in a similar manner to serum progesterone concentrations during pregnancy in rats, and suggested an important role for these scavenging enzymes in the regulation of luteal function.

${ }^{*}$ Correspondence.

Received 10 May 1995.
Prostaglandin $\mathrm{F}_{2 u}\left(\mathrm{PGF}_{2 u}\right)$ is involved in corpus luteum regression (Rothchild, 1981; Olofsson and Selstam, 1988), at least in part, through the increase of reactive oxygen species in rats (Sawada and Carlson, 1989, 1991, 1994a; Riley and Behrman, 1991; Aten et al., 1992). However, the effects of $\mathrm{PGF}_{2 \mu}$ on scavenging systems such as SOD and $\mathrm{GP}_{\mathrm{x}}$ in the corpus luteum are unknown. In addition, the luteolytic effects of $\mathrm{PGF}_{2 u}$ depend on the age of the corpus luteum in rats (Khan et al., 1979; Lahav et al., 1988, 1989).

The present study was designed to clarify the changes in lipid peroxide concentrations and the activities of antioxidant enzymes in the corpus luteum during pseudopregnancy in rats, and to study the effects of $\mathrm{PGF}_{2 \alpha}$ on lipid peroxides and antioxidant enzymes at different ages of the corpus luteum.

\section{Materials and Methods}

\section{Animals}

Sprague-Dawley rats, $220-270 \mathrm{~g}$, were housed under controlled conditions (lights on from 05:00 to 19:00 h) with free 
access to standard rat chow and water. Vaginal smears were obtained daily, and only those rats showing two consecutive 4 day oestrous cycles were used. Pseudopregnancy was induced by mechanical stimulation of the uterine cervix for about I min with a glass rod at 18:00 h at pro-oestrus and at 9:00 h at oestrus. The last day on which the rat exhibited an oestrous smear was designated as day 1 of pseudopregnancy. Vaginal smears from pseudopregnancy were checked every day.

\section{Experimental protocol}

Experiment 1. Operations were carried out between 16:00 and $18: 00 \mathrm{~h}$ on days $1,3,5,7,9,11$ or 13 of pseudopregnancy. Rats underwent laparotomy under ether anaesthesia. After sampling blood from the portal vein, the ovaries were perfused with saline via the portal vein during draining of the inferior vena cava, to remove the blood, as reported by Sugino et al. (1993a). The ovaries were removed, and the corpus luteum was dissected, cleaned of adhering tissue in a watch glass and weighed. For SOD or $\mathrm{GP}_{\mathrm{x}}$ assay, the corpus luteum was homogenized with Tris- $\mathrm{HCl}$ buffer $\left(0.01 \mathrm{~mol} \mathrm{l}^{-1}, \mathrm{pH} 7.4\right)$ and centrifuged at $800 \mathrm{~g}$ for $10 \mathrm{~min}$ at $4^{\circ} \mathrm{C}$, and the supernatant was stored at $-70^{\circ} \mathrm{C}$. For the lipid peroxide assay, the corpus luteum was homogenized with $1.15 \%(\mathrm{w} / \mathrm{v}) \mathrm{KCl}$ and the homogenate was stored at $-70^{\circ} \mathrm{C}$. The serum samples were stored at $-20^{\circ} \mathrm{C}$ for progesterone assay.

Experiment 2. The effects of $\mathrm{PGF}_{2 \alpha}$ on the production of lipid peroxides and antioxidant enzymes in the corpus luteum were studied by injecting rats with $\mathrm{PGF}_{2 u}\left(3 \mathrm{mg} \mathrm{kg}^{-1}\right.$ body

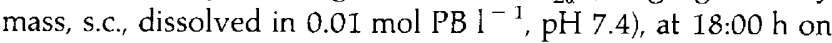
day 7,9 or 12 of pseudopregnancy. PGF $_{2 \alpha}$ was the kind gift of Ono Pharmaceutical Co. Ltd (Osaka). Control rats received saline (s.c.). Each group of rats was autopsied under ether anaesthesia before or $2 \mathrm{~h}$ after $\mathrm{PGF}_{2 \mu}$ injection as described in Expt I. Blood samples were taken and the ovaries were removed and used to determine serum progesterone concentrations, enzyme activities and lipid peroxide concentrations in the corpus luteum.

\section{SOD assay}

Total SOD activity and Mn-SOD activity in the corpus luteum were measured using the method described by Sugino et al. (1993a), based on the nitrite method of Oyanagui (1984). The amount of protein required for $50 \%$ inhibition in the absorbance at $550 \mathrm{~nm}$ was defined as one unit (Nitrite Unit; $\mathrm{NU}$ ) of SOD activity. All data were expressed in NU of SOD activity $\mathrm{mg}^{-1}$ protein. Protein concentration was determined using the method described by Lowry et al. (1951). Cu, Zn-SOD activity was determined by subtracting Mn-SOD activity from the total SOD activity. The intra- and interassay coefficients of variation were $3.8 \%$ and $9.6 \%$, for the total SOD assay, and $4.7 \%$ and $6.4 \%$ for the Mn-SOD assay, respectively.

\section{$G P_{x}$ assay}

$\mathrm{GP}_{\mathrm{x}}$ activity in the corpus luteum was measured using the method described by Sugino et al. (1993b), based on the coupling of the enzyme to NADPH via glutathione reductase (Paglia and Valentine, 1967). The activity of $\mathrm{GP}_{x}$ was defined as $\mu \mathrm{mol}$ NADPH oxidized $\mathrm{min}^{-1} \mathrm{mg}^{-1}$ protein.

\section{Lipid peroxide assay}

Concentrations of lipid peroxides in the corpus luteum were measured by the thiobarbituric acid method of Ohkawa $e t$ al. (1979). The results were expressed as nmol of malondialdehyde (MDA) $\mathrm{g}^{-1}$ wet mass of tissue.

\section{Progesterone assay}

Serum progesterone concentrations were determined by the specific radioimmunoassay described by Kato et al. (1982). The sensitivity of the assay was $100 \mathrm{pg}$ per tube, and the intraand interassay coefficients of variation were $7 \%$ and $14.4 \%$, respectively.

\section{Statistical analyses}

Data were examined by analysis of variance and Duncan's new multiple range test. Differences were considered to be significant if $P<0.05$.

\section{Results}

$\mathrm{Cu}, \mathrm{Zn}-\mathrm{SOD}$ and $\mathrm{Mn}-\mathrm{SOD}$ activities in the corpus luteum changed in a similar manner to total SOD activity, which significantly $(P<0.01)$ increased from day $I$ to day 9 and decreased thereafter (Table 1$). \mathrm{GP}_{\mathrm{x}}$ significantly $(P<0.01$ ) increased from day 1 to day 3 , remained high until day 11 , and slightly decreased on day 13 of pseudopregnancy.

Total SOD activity in the corpus luteum and serum progesterone concentrations changed in parallel during pseudopregnancy, gradually increased until day 9 of pseudopregnancy and decreased thereafter (Fig. 1). A positive correlation was found between serum progesterone concentration and total SOD activity $(r=0.71, P<0.01)$. The mass of the corpus luteum gradually increased from day 1 to day 13 of pseudopregnancy. Lipid peroxide concentrations in the corpus luteum also gradually increased from day 3 to day 13 of pseudopregnancy (Fig. 1).

$\mathrm{PGF}_{2 \alpha}$ significantly decreased serum progesterone concentrations on days 7 and 9 , but not on day 12 of pseudopregnancy (Fig. 2). PGF $_{2 \alpha}$ significantly increased lipid peroxide concentrations in the corpus luteum on days 7 and 9 of pseudopregnancy, and further increased them on day 12 of pseudopregnancy (Fig. 2). The lipid peroxide concentrations induced by $\mathrm{PGF}_{2 \alpha}$ on day 12 of pseudopregnancy were significantly higher than those on day 7 or 9 of pseudopregnancy. Total SOD activity in the corpus luteum was increased by $\mathrm{PGF}_{2 u}$ on days 7 and 9 of pseudopregnancy, but not on day 12 of pseudopregnancy (Fig. 2). The total SOD activity in the corpus luteum on day 12 of pseudopregnancy was significantly lower than that on day 7 or 9 of pseudopregnancy in each group. $\mathrm{PGF}_{2 a}$ did not cause any 
Table 1. Changes in total superoxide dismutase (SOD), $\mathrm{Cu}, \mathrm{Zn}-\mathrm{SOD}, \mathrm{Mn}-\mathrm{SOD}$ and glutathione peroxidase $\left(\mathrm{GP}_{\mathrm{x}}\right)$ activities in the corpus luteum during pseudopregnancy

\begin{tabular}{|c|c|c|c|c|c|}
\hline $\begin{array}{l}\text { Day of } \\
\text { pseudopregnancy }\end{array}$ & $n$ & $\begin{array}{l}\text { Total SOD activity } \\
\text { (NU } \mathrm{mg}^{-1} \text { protein) }\end{array}$ & $\begin{array}{l}\mathrm{Cu}, \mathrm{Zn}-\mathrm{SOD} \text { activity } \\
\text { (NU mg }{ }^{-1} \text { protein) }\end{array}$ & $\begin{array}{l}\text { Mn-SOD activity } \\
\text { (NU } \mathrm{mg}^{-1} \text { protein) }\end{array}$ & $\begin{array}{c}\mathrm{GP}_{x} \text { activity } \\
\left(\mu \mathrm{mol} \mathrm{NADPH} \times 10^{-3}\right. \\
\left.\min ^{-1} \mathrm{mg}^{-1} \text { protein }\right)\end{array}$ \\
\hline 1 & 6 & $57.4 \pm 5.7^{\mathrm{a}}$ & $52.8 \pm 4.6^{\mathrm{a}}$ & $4.6 \pm 2.6^{b}$ & $1.80 \pm 0.23^{a}$ \\
\hline 3 & 5 & $115.2 \pm 5.0$ & $106.2 \pm 5.0$ & $9.0 \pm 1.3$ & $2.63 \pm 0.18$ \\
\hline 5 & 8 & $137.3 \pm 4.8$ & $123.0 \pm 5.4$ & $14.3 \pm 1.3$ & $2.68 \pm 0.10$ \\
\hline 7 & 6 & $158.0 \pm 6.3$ & $135.3 \pm 8.2$ & $22.7 \pm 2.0$ & $2.73 \pm 0.15$ \\
\hline 9 & 6 & $172.2 \pm 3.3$ & $152.7 \pm 4.4$ & $19.5 \pm 3.0$ & $3.28 \pm 0.19$ \\
\hline II & 8 & $150.1 \pm 5.3$ & $120.4 \pm 5.2$ & $29.7 \pm 2.1$ & $3.31 \pm 0.15$ \\
\hline 13 & 5 & $107.7 \pm 14.0^{\mathrm{b}}$ & $93.8 \pm 12.1^{b}$ & $13.9 \pm 4.2^{c}$ & $2.78 \pm 0.06$ \\
\hline
\end{tabular}

Values are means \pm SEM for the number of animals given; NU: nitrite unit.

${ }^{a} P<0.01$ compared with the other days; ${ }^{b} P<0.01$ compared with days 5, 7, 9 and 11 ; ${ }^{c} P<0.05$ compared with day 7 (Duncan's new multiple range test).

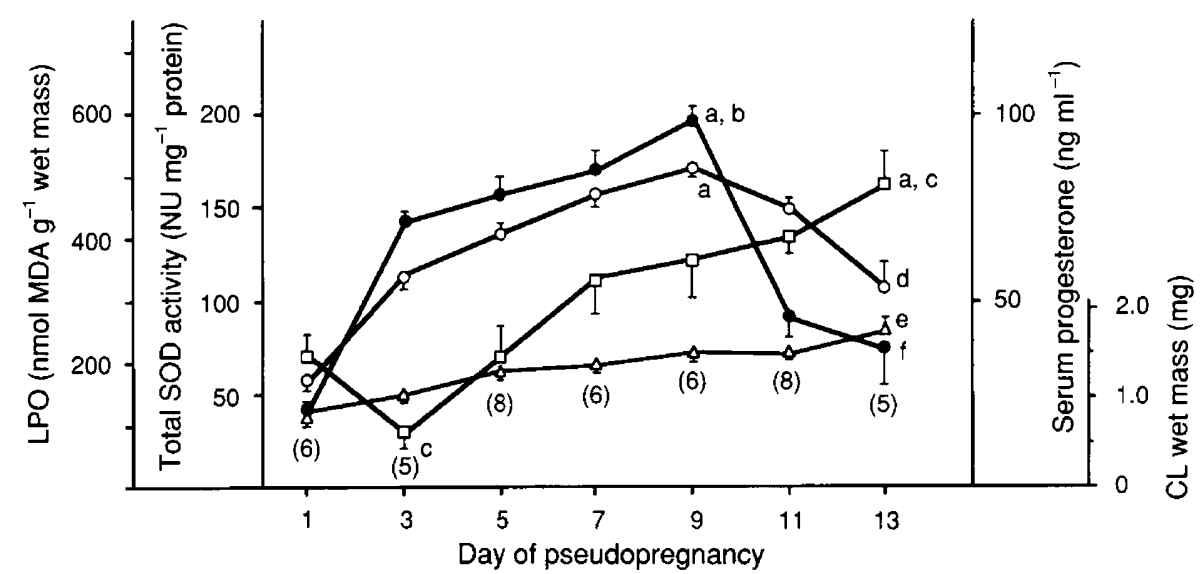

Fig. 1. Changes in serum progesterone concentration (•), total superoxide dismutase (SOD) activity $(O)$, lipid peroxide (LPO) concentration ( $\square$ ) in the corpus luteum (CL) and CL masses ( $)$ ) during pseudopregnancy. MDA: malondialdehyde. Values are means \pm SEM for the number of animals given in parentheses. ${ }^{a} P<0.01$ compared with days 1,3 and 5 ; ${ }^{b} P<0.05$ compared with day $7 ;{ }^{c} P<0.05$ compared with days 7 and $9 ;{ }^{d} P<0.01$ compared with days $5,7,9$ and 11 ; ${ }^{\mathrm{e}} P<0.01$ compared with the other days; and $P<0.01$ compared with days $3,5,7$ and 9 (Duncan's new multiple range test).

significant changes in $\mathrm{GP}_{\mathrm{x}}$ activity on days 7,9 and 12 of pseudopregnancy (data not shown).

\section{Discussion}

The present study confirms that lipid peroxide concentrations in the corpus luteum gradually increase towards the end of pseudopregnancy. It is not fully understood, however, why serum progesterone values were high from day 3 to day 9 of pseudopregnancy in spite of the increasing production of lipid peroxides in the corpus luteum. The inhibitory effect of lipid peroxides on progesterone production may be blocked by some factors during the mid-luteal phase. This may be supported by the findings of Sawada and Carlson (1994b) that progesterone secretion was increased by $\mathrm{LH}$ in spite of the increase of superoxide radical generation in pseudopregnant rats. In addition, the amount of lipid peroxides may not be enough to suppress the luteal function during the mid-luteal phase. However, SOD scavenges superoxide radicals by catalysing them to hydrogen peroxide, which is further converted to $\mathrm{H}_{2} \mathrm{O}$ by $\mathrm{GP}_{\mathrm{x}}$. Although neither superoxide radical nor hydrogen peroxide concentrations were measured in the present study, the increasing activities of SOD and $\mathrm{GP}_{\mathrm{x}}$ would have reduced these reactive oxygen species and contributed to the maintenance of luteal function during the mid-luteal phase. Hesla et al. (1992) reported that ovarian progesterone production is significantly and positively correlated with Mn-SOD activity throughout pseudopregnancy in rabbits. Previous data from our laboratory also demonstrate that serum progesterone concentrations change in a similar manner to the luteal SOD and $\mathrm{GP}_{\mathrm{x}}$ activities in pregnant rats (Sugino et al., 1993a; Sugino and Kato, 1994), and that SOD, in the presence of catalase, apparently blocks the antisteroidogenic effect of reactive oxygen species induced by ischaemia-reperfusion injury of the 
(a)
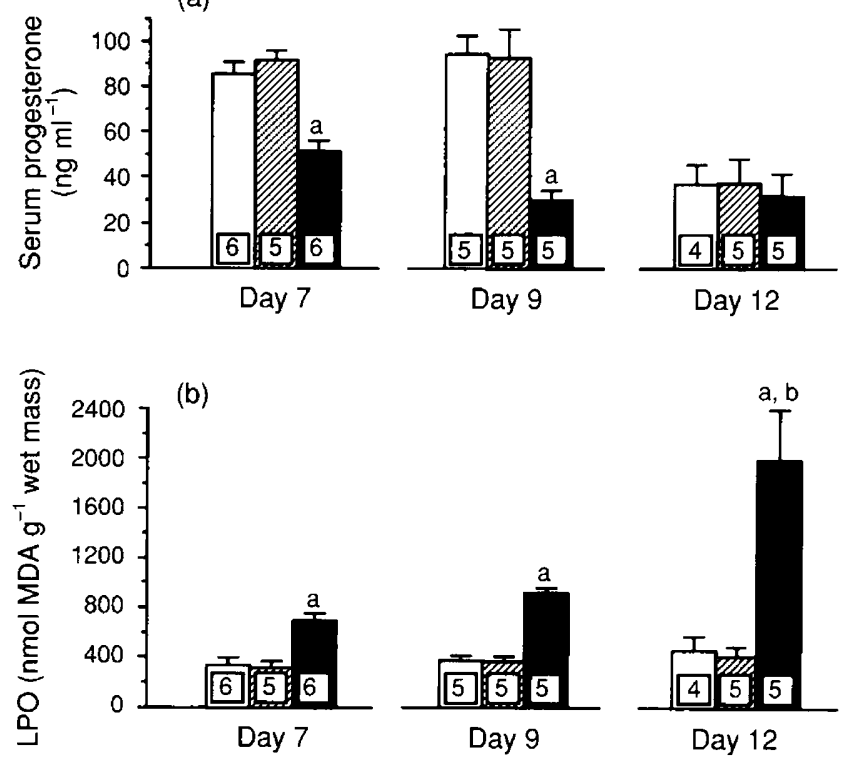

(c)

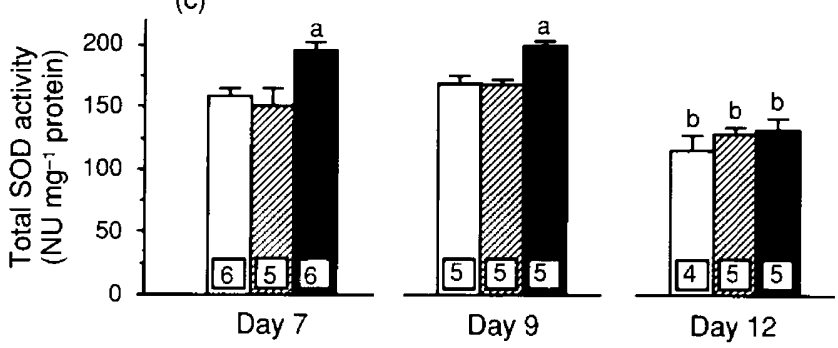

Fig. 2. Effects of $\mathrm{PGF}_{2: u}\left(3 \mathrm{mg} \mathrm{kg}{ }^{-1}\right.$, s.c.) treatment on (a) serum progesterone concentrations, (b) lipid peroxide (LPO) concentrations and (c) total superoxide dismutase (SOD) activities in the corpus luteum on days 7,9 and 12 of pseudopregnancy. $(0 \mathrm{~h}, \square ; 2 \mathrm{~h}$ after saline injection, 䬑; $2 \mathrm{~h}$ after $\mathrm{PGF}_{2 u}$ injection, $\mathbf{0}$ ). NU: nitrite unit; MDA: malondialdehyde. Each bar represents the mean \pm SEM for the number of animals shown. ${ }^{a} P<0.01$ compared with the saline group and ${ }^{b} P<0.01$ compared with the same group on the other days of pseudopregnancy (Duncan's new multiple range test).

ovary (Sugino et al., 1993b). These findings indicate the reciprocal relationship between reactive oxygen species and their scavengers in the regulation of luteal function.

$\mathrm{PGF}_{2 \ltimes}$ generates reactive oxygen species to induce luteolysis (Sawada and Carlson, 1989, 1991, 1994a; Riley and Behrman, 1991; Aten ef al., 1992). The present study further demonstrated that these oxidative effects of $\mathrm{PGF}_{2 u}$ changed as the age of the corpus luteum advanced; $\mathrm{PGF}_{2 u}$ induced a fivefold increase in lipid peroxide concentrations in the corpus luteum on day 12, but only twofold increases on days 7 or 9 of pseudopregnancy. The findings that serum progesterone increased from day 3 to day 9 of pseudopregnancy in spite of the increased lipid peroxide concentrations may be controversial to the results that serum progesterone was decreased with the increased lipid peroxides induced by $\mathrm{PGF}_{2 \alpha}$. This may be because $\mathrm{PGF}_{2 u}$ induced much greater amounts of lipid peroxides, which were actually greater than those on day 13 of pseudopregnancy. The role of the greater induction of lipid peroxides on day 12 of pseudopregnancy is unclear, but it may play a role in the accumulation of macrophages in the corpus luteum that precedes luteolysis by phagocytosis, as demonstrated in the pathogenesis of atherosclerosis (Steinberg et al., 1989).

Injected $\mathrm{PGF}_{2 u}$ could increase SOD activity in the corpus luteum on days 7 and 9 , but not on day 12 of pseudopregnancy. Since superoxide radicals by themselves stimulate SOD activity (Hassan and Fridovich, 1977; Dryer et al., 1980), the $\mathrm{PGF}_{24}$-induced superoxide radicals may stimulate SOD production, i.e. the corpus luteum on day 7 or 9 may have a greater responsiveness against the increase of superoxide radicals to induce SOD. In addition, during the regression phase, the number of macrophages is increased in the corpus luteum (Brännström et al., 1994). Since $\mathrm{PGF}_{2 u}$ stimulated superoxide radical production by macrophages in our unpublished data, the production of hydrogen peroxide by macrophages (Fantone and Ward, 1982) should also be increased. Since hydrogen peroxide inhibits SOD activities (Hodgson and Fridovich, 1975), PGF $_{2 u}$ may decrease SOD activity through macrophages. Also, during the regression phase, the ovarian blood flow decreases (Nett et al., 1976; Pang and Behrman, 1979), and the xanthine-xanthine oxidase system is activated, which induces superoxide radicals in the presence of oxygen (McCord, 1985). This is the same mechanism as ischaemia-reperfusion injury (Yoshikawa et al., 1989), and inhibits SOD activity in the corpus luteum on day 12 of pseudopregnancy (Sugino et al., 1993b). These possibilities may explain why SOD activities in the corpus luteum were not increased by $\mathrm{PGF}_{2 u}$ on day 12 of pseudopregnancy.

There was a clear discrepancy in the present study between the changes in serum progesterone concentration and luteal mass after day 9 of pseudopregnancy. Wang et al. (1993) reported that functional luteolysis, defined as a decrease in serum progesterone, and structural luteolysis, characterized as involution of the corpus luteum, are clearly separate events in rats. Niswender et al. (1994) also suggested that morphological luteolysis induced by $\mathrm{PGF}_{2 \mu}$ is manifested through apoptosis, which does not need the activation of the protein kinase $\mathrm{C}$ system, which is necessary to mediate the antisteroidogenic effects of $\mathrm{PGF}_{2 u}$ (Leung et al., 1986; Gibori et al., 1988). The present study indicates that the regulation of progesterone production may be independent of the regulation of luteal masses.

In summary, the present study indicated that lipid peroxides and antioxidant enzymes play important roles in regulating luteal function during pseudopregnancy, and that $\mathrm{PGF}_{2 u}$ in the corpus luteum may contribute to its regression through lipid peroxidation.

\section{References}

Aten RF, Duarte KM and Behrman HR (1992) Regulation of ovarian antioxidant vitamins, reduced glutathione, and lipid peroxidation by luteinizing hormone and prostaglandin $\mathrm{F}_{2 \prime \prime}$ Biology of Reproduction 46 401-407

Behrman HR and Aten RF (1991) Evidence that hydrogen peroxide blocks hormone-sensitive cholesterol transport into mitochondria of rat luteal cells Endocrinology 128 2958-2966

Behrman HR and Preston SL (1989) Luteolytic actions of peroxide in rat ovarian cells Endocrinology 124 2895-2900 
Brännström M, Giesecke L, Moore IC, Van Den Heuvel CJ and Robertson SA (1994) Leukocyte subpopulations in the rat corpus luteum during pregnancy and pseudopregnancy Biology of Reproduction 50 1161-1167

Dryer SE, Dryer RL and Autor AP (1980) Enhancement of mitochondrial, cyanide-resistant superoxide dismutase in the livers of rats treated with 2,4-dinitrophenol The Journal of Biological Chemistry 255 1054-1057

Fantone JC and Ward PA (1982) Role of oxygen-derived free radicals and metabolites in leukocyte-dependent inflammatory reactions American Journal of Pathology 107 397-418

Gatzuli E, Alter RF and Behrman HR (1991) Inhibition of gonadotropin action and progesterone synthesis by xanthine oxidase in rat luteal cells Endocrinology 128 2253-2258

Gibori G, Khan I, Warshaw ML, McLean MP, Puryear TK, Nelson S, Durkee TJ Azhar S, Steinschneider A and Rao MC (1988) Placental-derived regulators and the complex control of luteal cell function Recent Progress in Hormone Research 44 377-429

Hassan HM and Fridovich I (1977) Regulation of the synthesis of superoxide dismutase in Escherichia coli The Joumal of Biological Chemistry 252 $7667-7672$

Hesla IS, Miyazaki T, Dasko LM, Wallach EE and Dharmarajan AM (1992) Superoxide dismutase activity, lipid peroxide production and corpus luteum steroidogenesis during natural luteolysis and regression induced by oestradiol deprivation of the ovary in pseudopregnant rabbits Journal of Reproduction and Fertility $95915-924$

Hodgson EK and Fridovich I (1975) The interaction of bovine erythrocyte superoxide dismutase with hydrogen peroxide: inactivation of the enzyme Biochemistry 14 5294-5299

Kato H, Ueda K, Tsutsui H, Miyauchi F and Torigoe T (1982) Role of the nongravid part of the uterus in the regulation of corpus luteum function in pregnant rats Endocrinology 111 2020-2024

Khan MI, Rosberg S, Lahav M, Lamprecht SA, Selstam G, Herlitz. H and Ahrén K (1979) Studies on the mechanism of action of the inhibitory effect of prostaglandin $\mathrm{F}_{2 \mathrm{x}}$ on cyclic AMP accumulation in rat corpora lutea of various ages Biology of Reproduction 21 1175-1183

Kodaman PH, Aten RF and Behrman HR (1994) Lipid hydroperoxides evoke antigonadotropic and antisteroidogenic activity in rat luteal cells Endocrinology 135 2723-2730

Lahav M, West LA and Davis JS (1988) Effects of prostaglandin $F_{2 w}$ and a gonadotropin-releasing hormone agonist on inositol phospholipid metabolism in isolated rat corpora lutea of various ages Endocrinology 123 1044-1052

Lahav M. Davis IS and Rennert H (1989) Mechanism of the luteolytic action of prostaglandin F-2 $\alpha$ in the rat Journal of Reproduction and Fertility Supplement $37233-240$

Leung PCK, Minegishi T, Ma F, Zhou F and Ho-Yuen B (1986) Induction of polyphosphoinositide breakdown in rat corpus luteum by prostaglandin $\mathrm{F}_{2 u}$ Endocrinology 119 12-18

Lowry OH, Rosebrough NJ, Farr AL and Randall RJ (1951) Protein measurement with the folin phenol reagent Journal of Biological Chemistry $193265-275$

McCord JM (1985) Oxygen-derived free radicals in postischemic tissue injury The New England Journal of Medicine 312 159-163

Musicki B, Aten RF and Behrman HR (1994) Inhibition of protein synthesis and hormone-sensitive steroidogenesis in response to hydrogen peroxide in rat luteal cells Endocrinology 134 588-595
Nett TM, McClellan MC and Niswender GD (1976) Effects of prostaglandins on the ovine corpus luteum: blood flow, secretion of progesterone and morphology Biology of Reproduction 15 66-78

Niswender GD, Juengel JL, McGuire WJ, Belfiore CJ and Wiltbank MC (1994) Luteal function: the estrous cycle and early pregnancy Biology of Reproduction $50239-247$

Ohkawa H, Ohishi N and Yagi K (1979) Assay for lipid peroxides in animal tissues by thiobarbituric acid reaction Analytical Biochemistry 95 351-358

Olofsson J and Selstam G (1988) Changes in corpus luteum content of prostaglandin $\mathrm{F}_{2 \alpha}$ and $\mathrm{E}$ in the adult pseudopregnant rat Prostaglandins 35 $31-40$

Oyanagui Y (1984) Reevaluation of assay methods and establishment of kit for superoxide dismutase activity Analytical Biochemistry 142 290-296

Paglia DE and Valentine WN (1967) Studies on the quantitative and qualitative characterization of erythrocyte glutathione peroxidase The Journal of Laboratory and Clinical Medicine 70 158-169

Pang CY and Behrman HR (1979) Relationship of luteal blood flow and corpus luteum function in pseudopregnant rats American Journal of Physiology 237 E30-E34

Riley JCM and Behrman HR (1991) In vivo generation of hydrogen peroxide in the rat corpus luteum during luteolysis Endocrinology 128 1749-1753

Rothchild I (1981) The regulation of the mammalian corpus luteum Recent Progress in Hormone Research 37 183-298

Sawada M and Carlson JC (1989) Superoxide radical production in plasma membrane samples from regressing rat corpora lutea Canadian Journal of Physiology and Pharmacology 67 465-471

Sawada M and Carlson JC (1991) Rapid plasma membrane changes in superoxide radical formation, fluidity, and phospholipase $A_{2}$ activity in the corpus luteum of rat during induction of luteolysis Endocrinology 128 2992-2998

Sawada M and Carlson JC (1994a) Studies on the mechanism controlling generation of superoxide radical in luteinized rat ovaries during regression Endocrinology 135 1645-1650

Sawada M and Carlson JC (1994b) LH stimulation of superoxide radical generation and the effect of superoxide dismutase on steroidogenesis Biology of Reproduction 50144 (Supplement)

Steinberg D, Parthasarathy S, Carew TE, Khoo JC and Witztum JL (1989) Modifications of low-density lipoprotein that increase its atherogenicity The New England Journal of Medicine 14 915-924

Sugino $\mathrm{N}$ and Kato $\mathrm{H}$ (1994) The role of ischemia-reperfusion injuries in generating reactive oxygen species during luteolysis Advance in Contraceptive Delivery System 10 95-106

Sugino N, Nakamura Y, Takeda O, Ishimatsu M and Kato H (1993a) Changes in activities of superoxide dismutase and lipid peroxide in corpus luteum during pregnancy in rats Journal of Reproduction and Fertility 97 347-351

Sugino N, Nakamura Y, Okuno N, Ishimatsu M, Teyama T and Kato H (1993b) Effects of ovarian ischemia-reperfusion on luteal function in pregnant rats Biology of Reproduction 49 354-358

Wang F, Riley JCM and Behrman HR (1993) Immunosuppressive levels of glucocorticoid block extrauterine luteolysins in the rat Biology of Reproduction $4966-73$

Yoshikawa T, Ueda S, Naito Y, Takahashi S, Oyamada H, Morita Y, Yoneta T and Kondo M (1989) Role of oxygen-derived free radicals in gastric mucosal injury induced by ischemia or ischemia-reperfusion in rats Free Radical Research Communications 7 285-291 